\title{
Student Collaboration and Teacher-Directed Classroom Dynamic Assessment: A Complementary Pairing
}

\author{
Kristin Davin \\ kdavin@luc.edu \\ Richard Donato \\ University of Pittsburgh - Main Campus, donato@pitt.edu
}

Follow this and additional works at: https://ecommons.luc.edu/education_facpubs

Part of the Education Commons

\section{Author Manuscript}

This is a pre-publication author manuscript of the final, published article.

\section{Recommended Citation}

Davin, Kristin and Donato, Richard. Student Collaboration and Teacher-Directed Classroom Dynamic Assessment: A Complementary Pairing. Foreign Language Annals, 46, 1: , 2013. Retrieved from Loyola eCommons, Education: School of Education Faculty Publications and Other Works, http://dx.doi.org/ 10.1111/flan. 12012

This Article is brought to you for free and open access by the Faculty Publications and Other Works by Department at Loyola eCommons. It has been accepted for inclusion in Education: School of Education Faculty Publications and Other Works by an authorized administrator of Loyola eCommons. For more information, please contact ecommons@luc.edu.

\section{c) (†) $\ominus$}

This work is licensed under a Creative Commons Attribution-Noncommercial-No Derivative Works 3.0 License. (C) 2013 American Council on the Teaching of Foreign Languages. 


\title{
Student collaboration and classroom dynamic assessment: A complementary pairing?
}

\begin{abstract}
This article examines collaboration during small group tasks with young novice level language learners studying Spanish. After five days of classroom dynamic assessment (DA) targeting WHquestion formation, students worked in small groups on a collaborative writing task. This research sought to determine whether learners were able to mediate their peers during this task and if so, whether this mediation might be traced back to participation in classroom DA. Findings revealed that students drew upon collective knowledge to complete the task. While the learners did not appropriate forms of mediation used during DA, they did provide scaffolding in other ways. We conclude that classroom DA can be supplemented by small group tasks and that assistance, albeit in different forms, emerges in these two contexts.
\end{abstract}

\section{Keywords: Peer scaffolding, Small Group Work, Sociocultural Theory, FLES, Dynamic Assessment}

The purpose of the present study is to examine whether small group collaborative tasks complement classroom dynamic assessment (DA) in a primary school language classroom. Although the majority of DA research has taken place in one-on-one interactions (Ableeva, 2008; Antón, 2009; Poehner, 2005, 2007), recent work has shown the utility of using the DA framework to unite instruction and assessment within the classroom context (Davin, in press, 2011; Lantolf \& Poehner, 2011a; Poehner, 2009). Davin (in press) described how a teacher simultaneously taught and assessed WH-question (who, what, when, where, why) formation by following a list of pre-scripted prompts in response to anticipated student errors. However, she noted that due to time constraints and the large number of students in a classroom, classroom DA alone, while effective for those students who actively participated, was not sufficient to promote and monitor the language development of every student in a classroom. In classroom DA, a teacher guides language development by assessing students' actual level of development from 
which a zone of proximal development (ZPD) for individual students can be identified (Lantolf \& Poehner, 2011a). Once actual levels of development (here the students' ability to use and form WH-questions in Spanish) are identified, carefully tailored mediation can be provided to move beyond what students can only accomplish with the assistance of a more knowledgeable other (Davin, in press; Lantolf \& Poehner, 2011a, 2011b; Poehner, 2009). By providing contingent and graduated mediation in the form of questions, hints, or prompts (Aljaafreh \& Lantolf, 1994), the teacher pushes the language development of the student forward by simultaneously assessing current performance, identifying the presence of certain maturing abilities in the language, and providing meaningful intervention (Chaiklin, 2003; Lantolf \& Poehner, 2004; Lidz \& Gindis, 2003; Valsiner, 2001).

One critical issue raised in the context of classroom DA is that only selected students are given opportunities to respond actively to teacher mediation. This, in turn, limits the cognitive engagement of a majority of students in benefitting from the teacher's mediation (Davin, 2011; Poehner, 2009). Although silent classmates are exposed as peripheral participants (Lave \& Wenger, 1991) to the dialogic mediation provided by the teacher to individual students, the effect on these observers is not entirely clear or assured (Davin, in press; Poehner, 2009). This is particularly true for the teacher who is engaged in the moment in a dynamic assessment of the student's maturing ability with the language. Therefore, many students often need additional assistance tailored to their individual needs to develop the language concept under study. The purpose of this paper is to explore one such practice, small group work, in the context of a classroom DA procedure as a way of exploring the potential complementary contribution of peer collaboration to a teacher's DA with the entire class. 
Small group work is a classroom configuration that offers students an arena in which every student can participate, explore the language, and potentially provide and receive peer assistance on cognitively challenging language tasks. Group work both shifts the responsibility for learning from the teacher to the student and improves achievement and student attitudes (Smith, 1987). When students are placed in small groups to complete a collaboratively designed pedagogical task in the classroom, all students are compelled to participate. Through this social interaction, students who might not normally participate in the whole class setting are drawn into the activity and allowed to verbalize their thoughts, questions, and confusions (Brooks \& Donato, 1994; Swain, Lapkin, Knouzi, Suzuki, \& Brooks, 2009). The small group configuration offers a 'safe' space (Curtain \& Dahlberg, 2010, p. 98) in which confusions and struggles with language concepts can arise (and potentially be resolved) without the fear of losing face in front of the whole class. Through languaging, "the process of making meaning and shaping knowledge and experience through language" (Swain, 2006, p. 98) students are able to verbalize their thinking and transform "inner thoughts to external knowing" (Swain et al., 2009, p. 5).

While classroom DA offers some students the opportunity to receive direct mediation from their teachers, small group work offers all students the possibility of additional support from their peers. In her work on the patterns of negotiation for meaning with young learners, Oliver (2002) reports that peers are "an important source of data about the target language" and that "the use of peers in teaching practices would appear to be justified whether it is in the adult context or in a primary school setting" (p. 108). Substantial research on peer assistance at varying levels—middle school (Swain \& Lapkin, 1998), high school (Alley, 2005; Brooks \& Donato, 1994), university (Brooks, Donato, \& Mcglone, 1997; De Guerrero \& Villamil, 2000; Donato, 1994; Ohta, 2000, 2005), and adult classrooms (Antón \& DiCamilla, 1998; DiCamilla \& 
Antón, 1997) has shown that students can assume responsibility for assisting their peers during small group work. This assistance is sometimes referred to as peer scaffolding, defined as "those supportive behaviors by which one partner in a semiotically mediated interactive situation can help another to achieve higher levels of regulation" (De Guerrero \& Villamil, 2000, p. 56) for a particular task. In the small group context, Donato (1994) has referred to some forms of peer assistance as collective scaffolding where no one individual directs the course of assistance but rather it is distributed across all participants during joint activity.

The scaffolding process, as we define it, involves recruitment of interest to a task, reduction in the number of constituent acts required by a task, maintaining the objective of a task for a learner, marking critical features of the task, frustration control, and demonstration (Wood, Bruner, \& Ross, 1976).

Because no previous work has examined how small group work might complement classroom DA, we wondered if students might extend assistance to their peers after participating in whole class instruction that carefully followed DA procedures, and if so, how this assistance might be carried out. The fact that the present study took place in a primary school classroom added another unknown element to our research because previous research suggests that age and proficiency level may play a role on the amount and nature of feedback during child interaction, as well as students' responses to feedback (de la Colina \& García Mayo, 2006; Mackey, Oliver, \& Leeman, 2003; Oliver \& Mackey, 2003; Oliver, 1998, 2000, 2002). Additionally, in the context of a class in which the teacher uses DA, it seems likely that peer assistance might occur more naturally than in classes where teachers do not regularly provide graduated assistance to students. One argument supporting this assumption is that in a class where DA is routinely used, students are socialized into a learning community where help is readily available and responsive 
to individual learners' current level of language development. From this perspective, we examined whether students participating in small group tasks might begin to appropriate the forms of mediation used by their teacher and whether working collaboratively in small groups might serve as a complement to classroom DA where individual attention to all students' developing abilities was not possible. ${ }^{1}$ The research questions that guided the present examination are: 1) Can young novice level language learners assist other's performance during small group collaborative tasks to complete a task that no student within the group can complete independently? 2) If so, in what ways do these learners assist each other's performance during task completion?, and 3) If peer assistance emerges during small group work, how is it similar or different from teacher mediation during DA?

\section{Conceptual Framework}

An examination of sociocultural learning theory developed by L.S. Vygotsky and his many adherents sheds light onto how processes of learning can occur through peer interaction during small group work. According to sociocultural theory, development is socially and culturally derived and occurs through human interaction (Cole \& Engeström, 1993; Vygotsky, 1978; Wertsch, 1985). A child learns to complete a novel task or solve a problem by utilizing varying forms of mediation provided by other people. Language is the primary means of mediation that operates between individuals during social interaction (Vygotsky, 1986). Speech, whether it occurs between people (Lantolf \& Poehner, 2004; Lantolf \& Thorne, 2006) or to oneself (Swain et al., 2009; Swain \& Lapkin, 1998) enables one to plan, coordinate, and review actions (Brooks \& Donato, 1994; Wells, 1999). Development occurs when these forms of external assistance are internalized (Vygotsky, 1978) and the child no longer requires mediation to regulate the task in 
question. Internalization occurs when humans bring externally formed mediating artifacts into thinking activity, resulting in an individual's ability to complete tasks that were once only possible through mediation from others (Lantolf \& Thorne, 2006).

In order for internalization to occur, the assistance provided during social interaction must be calibrated to the ZPD of the learner (Vygotsky, 1978; Wertsch \& Hickmann, 1987; Wertsch, 1979). The ZPD represents "the distance between the actual developmental level as determined by independent problem solving and the level of potential development as determined through problem solving under adult guidance or in collaboration with more capable peers" (Vygotsky, 1978, p. 86). Therefore, assistance must be just beyond what a learner can do independently (Aljaafreh \& Lantolf, 1994). If the assistance provided is beyond the range of potential development of the child, the child will not be able to complete the task even with guidance and internalization will not occur. If assistance is superfluous to the child, no potential for development exists.

The terminology used in this article is based on the theory outlined above. In the small group configuration, interaction among students as they work together toward a common goal is referred to as 'collaboration'. During collaboration, students often provide each other with 'assistance'. Assistance is a broad term that we further distinguish through the classification of 'mediation' or 'scaffolding'. Poehner (2008) argues that the difference lies in the purpose of the assistance, whether it is provided to help learners develop new cognitive functions (mediation) or whether it is provided to complete the task at hand (scaffolding). If the focus of assistance is on task completion with no attention to the broader conceptual issues underlying the activity, the term scaffolding is used. Our purpose in introducing the scaffolding metaphor is not to claim that peer scaffolding during collaborative tasks and teacher mediation during DA are identical either 
in theory or in practice. The goal of this research is, therefore, to examine whether the assistance that occurred was focused on task completion through peer scaffolding or development through mediation.

\section{Literature Review}

\section{Potential of Peer Scaffolding}

Following the premise of sociocultural theory that learning occurs through interaction, Donato (1994), in a seminal piece that shifted attention to the potential of peer scaffolding, found that students were capable of providing "guided assistance" to peers during collaborative interactions in ways that were characteristic of scaffolding as it is identified in the literature (Wood et al., 1976). He analyzed the interaction of university students studying French to ascertain whether students could co-construct language knowledge and found that "collaborative work among language learners provides the same opportunity for scaffolded help as in expert-novice relationships" (Donato, 1994, p. 41). Even when no expert is present, evidence has shown that students can pool resources and draw upon their collective knowledge to solve language problems (Brooks et al., 1997; Brooks \& Donato, 1994; Donato, 1994; Storch, 2002), suggesting that peers need not necessarily be 'more capable' and that expertise is a collective phenomenon. Others have continued this strand of research through the examination of varying aspects of small group work. Swain and Lapkin (1998) and DiCamilla and Antón (1997) also found that scaffolded help is not limited to expert-novice pairings. When groups are composed of a more and less proficient student, neither dominates the interaction and expertise is distributed in the 
interaction where individuals are individually novice and but collectively expert (Donato, 1994). Learners are often able to scaffold each other to solve problems and complete tasks through use of a variety of strategies that appear to be unconsciously sensitive to the ZPD (Lantolf, 2000; Swain \& Lapkin, 1998; van Lier, 2000), providing theoretical and empirical support that pair and group work are useful complements to large-group instruction.

\section{Characteristics of Peer Scaffolding}

A set of peer scaffolding strategies appear repeatedly in second language (L2) acquisition literature. Perhaps the most common strategy is repetition. In their work with adult Spanish learners, DiCamilla and Antón (1997) found that self and other repetition served to "distribute the scaffolded help throughout the activity, and thereby hold the scaffold in place, as it were, creating a cognitive space in which to work (e.g., think, hypothesize, evaluate), and from which to build (i.e., generate more language)" (pp. 627-628). Through her examination of clarification checks with $3^{\text {rd }}$ year university students studying Japanese, Ohta (2005) explored the varying functions of repetition and found that it was often used to 1) confirm understanding, 2) signal an error, 3) mark an unexpected utterance, or 4) express understanding to encourage a peer to continue.

Another common characteristic of both peer scaffolding and DA is the use of students' first language (L1). Within the literature on peer scaffolding, the use of the L1 is not always encouraged (Alley, 2005), although it serves an important function in collaborative dialogue (Antón \& DiCamilla, 1998; Brooks et al., 1997; Brooks \& Donato, 1994; Storch \& Aldosari, 2010; Swain \& Lapkin, 1998, 2000; Villamil \& De Guerrero, 1996). Communication in the L1 
can help to establish the tone and nature of the group work (Antón \& DiCamilla, 1998; Villamil \& De Guerrero, 1996) and can serve as a mediational tool to support and sustain interaction. L1 usage can serve varying functions such as moving the task along, focusing attention, and for interpersonal interaction (Swain \& Lapkin, 2000). During small group work, students' L1 can be used to create shared social worlds. Brooks and Donato (1994) classify this use of the L1 in as speaking as object regulation, speaking as shared orientation, and speaking as goal formation. The way that students approach a task cannot be externally defined and different groups may construct the task in different ways, depending on how they orient themselves (Brooks \& Donato, 1994; Swain \& Lapkin, 1998). Students working in small groups often use the L1 to 'reformulate the task goals' (Brooks \& Donato, 1994, p. 271), ensuring that all students understand and agree on the end product.

Language learners commonly revert to their L1 when they encounter difficulty in the target language. Brooks and Donato (1994) refer to this as metatalk, or talk about talk. Metatalk serves to both initiate and sustain small group work and is especially important for students at lower levels of proficiency. In their work with $8^{\text {th }}$ grade French immersion students, Swain and Lapkin (1998) found that the L1 was frequently used to attend to linguistic form and solve lexical problems. Serving all of these functions, the L1 is "a critical psychological tool that enables learners to construct effective collaborative dialogue in the completion of meaning-based language tasks" (Antón \& DiCamilla, 1998, p. 337).

These two forms of assistance that are so common to the literature related to peer scaffolding — repetition and use of the L1—also appear in the literature on DA. The use of repetition within the DA literature is often used to draw a learner's attention to an error (Antón, 2009; Davin, in press; Poehner, 2008, 2009). Use of the L1 in DA literature is more varied and 
often depends on the proficiency level of the learners or the objective of the assessment. However, examples of L1 usage for mediation are present in the work of Poehner (2008). Although the goal of scaffolding and mediation differ, the use of similar forms of assistance in both peer scaffolding during small group work and teacher mediation in DA illustrate the unity of task-specific learning and conceptual development.

\section{Context}

Data were gathered in a combined $4^{\text {th }}$ and $5^{\text {th }}$ grade FLES classroom composed of 17 students who had studied Spanish for 15 minutes daily for four consecutive years. The Spanish curriculum was composed of units of study grouped by theme for each grade level cluster. When data for the present study were collected, students in the combined $4^{\text {th }}$ and $5^{\text {th }}$ grade classroom were studying a unit devoted to the geography and culture of Argentina. Because the capstone project of this semester was an interview with an international student from Argentina, one unit within this theme consisted of a series of lessons focused on WH-question formation, heretofore referred to as the 'questioning unit'. Within the questioning unit, the teacher used the classroom DA framework during five class periods ( 75 minutes) to guide interaction within the whole group configuration (see Davin, in press). Within this framework, the teacher assessed current student performance and responded to student errors with a series of pre-scripted mediating prompts with the goal of measuring the distance between the actual and potential developmental levels (ZPD) of the learners (Table 1). As Table 1 indicates, a student requiring only Prompts 1 and 2 would be assessed as further along the developmental trajectory in the use of WHquestions than a student requiring Prompts 1 through 4. 
[Insert Table 1 here]

These prompts were graduated in that they were always provided in the order listed above, from most implicit to most explicit, and were contingent upon the child correctly forming the question. As the questioning unit progressed, the amount of mediation was adjusted dynamically for individual students depending on the type of prompt they needed. For example, for an individual student, day one of the unit might require Prompts 1 through 4 whereas that same student might require only Prompts 1 and 2 on Day 2.This reduction in the number of prompts required by the student (and therefore reduction in the level of explicitness) would signal to the teacher that the student was moving gaining control of the lexicogrammatical features of questions.

Task

After five days of following these prompts in the whole group configuration, the teacher placed students in small groups of three for three class periods (45 minutes). Students did not receive any training from the teacher on how to work collaboratively and were not given the explicit requirement to assist their peers. To prepare for the culminating oral interview with the Argentinean guest, students were asked to complete the collaborative group work task of preparing a list of questions. Evidence suggests that group tasks that incorporate both speaking and writing are more conducive to language learning because participants act as tutors, coauthors, sounding boards, and critical readers (Weissberg, 2006). Collaborative writing has garnered attention with L2 acquisition researchers working within the sociocultural theory (Foster, 2005; Leeser, 2004; Storch, 2001, 2005, 2011) because as talk is vocalized, its 
externalized form become an artifact that can be inspected, reflected upon, and explored (Storch, 2011). Collaborative writing therefore refers to "the joint production of the coauthoring of a text by two or more writers" (Storch, 2011, p. 276).

\section{Participants}

Although all 17 students in this Spanish class took part in the activities described in this study, six non-heritage language learners were selected as focus students. These six students were selected from those with parental consent because they represented a variety of proficiency levels and attended school regularly. The six focal students were divided into two groups. Table 2 lists the participants in each group and each student's proficiency rating. Language proficiency had been determined during the previous semester through the implementation of an Integrated Performance Assessment (Davin, Troyan, Donato, \& Hellman, 2011).

[Insert Table 2 here]

Students were grouped based on their proficiency level and the recommendations of their Spanish teacher (as recommended by Leeser, 2004). Of the focus students, two were NoviceLow, two were Novice-Mid, and two were Novice-High speakers of Spanish. Each group was composed of one student from each proficiency level.

Data Collection and Analysis 
To answer the research questions, we relied on three methods of data collection: video/audiorecording, non-participant observation, and artifact collection. During small group work, a video camera and digital audio recorder were placed in each of the two focus groups. Each group was given a different location nearby the classroom to work (the hallway and the teacher's office). During this 15-minute period, the first author circulated among groups and observed the interactions. At the end of the class period, the students turned in their list of questions to their teacher who passed along copies to the researchers.

To determine the extent of collaboration that occurred with each group, the transcripts were first divided into language-related episodes (LREs; Swain \& Lapkin, 1998). Each LRE began when a student first proposed or began to form a question and ended when the discussion or formation of that question was complete. Although there were few occurrences of off-task dialogue $^{2}$, those that did occur were excluded from the time calculations. To further understand the assistance that occurred, each transcript was analyzed using a microgenetic approach (Wertsch, 1985). To answer the research questions, we examined the LRE that corresponded to each WH-question formed by each group and timed the length of the LRE. We also examined the LREs for instances of repetition (DiCamilla \& Antón, 1997; Ohta, 2005) and use of the L1 (Antón \& DiCamilla, 1998; Brooks \& Donato, 1994; Brooks et al., 1997; Swain \& Lapkin, 1998, 2000; Villamil \& De Guerrero, 1996). Use of the L1 was further coded into the categories of metatalk (Brooks \& Donato, 1994), and talk about task (Brooks et al., 1997). Once these broad categories were identified, additional discourse moves were examined. To prevent reducing language to a series of figures and numbers in support of the argument that this quantification excludes the most meaningful data, the language itself (Brooks \& Donato, 1994; Nunan, 1992; 
Schegloff, 1993), multiple excerpts are presented to provide a more complete picture of the forms of assistance that occurred.

\section{Findings}

Research Question 1: Can young novice level language learners assist other's performance during small group collaborative tasks to complete a task that no student within the group can complete independently?

Despite their low level of proficiency in Spanish, the students in this classroom were able to pool their knowledge and create lists of questions. One indication of the collaboration that occurred within each group was the amount of time spent on the formation of each question. Tables 3 and 4 show the questions formed by each of the three focus groups and the amount of time spent talking about and forming each question.

[Insert Table 3 here]

[Insert Table 4 here]

The time required to form each question and observations of small group performance suggests that few questions were formed independently. While Group 1 was able to form their second question after only 28 seconds of dialogue, two of their questions took approximately one minute, one question took approximately two minutes, and another question required three minutes of dialogue. Group 2 followed a similar pattern. While their first question required 
approximately 17 seconds to record, their second question required almost a minute and their third and fourth questions required even more time. Although not all of these questions were grammatically accurate, eight of the nine questions were comprehensible (with the exception being Q2 in Table 3).

One additional observation that may be traced back to the classroom DA procedure is that only one of the nine questions formed contained an error in the selection of the interrogative word needed to elicit the information desired from the visitor. Errors more typically involved syntactic and grammatical considerations that were not made salient to the students during the previous classroom DA sessions. From this perspective, it might be claimed that DA supported the small group task by making the most relevant language information, posing specific questions, available for its use in this new context.

Research Question 2: If young novice level language learners can assist other's performance during small group collaborative tasks to complete a task that no student within the group can complete independently, in what ways do these learners assist each other's performance during task completion?

To understand how these novice level students were able to collaborate to prepare the lists of questions above, one excerpt from the dialogues of each of the two groups is presented in this section. The dialogue that occurred to record the groups' first question (listed as Q2 for Group 2 since Q1 was a memorized question) was selected for these excerpts because it highlights student performance immediately following classroom DA. That is to say, the dialogue that occurred to form the first question provides a window into where students were within their respective ZPD following classroom DA. What quickly becomes clear is that, after five days (75 minutes) of 
classroom DA targeting WH-question formation, the majority of students were not totally capable of independent performance. This does not suggest that development did not occur, however. Rather, what this observation points to is the need to complement classroom DA with other forms of mediated activity as a way to focus attention on the individual ZPDs of students and to provide the teacher with additional observational data for understanding the actual and potential development of students as a result of previous whole class DA.

In this section, we present an excerpt from each of the two groups followed by an analysis of the scaffolding techniques used by the students. After these excerpts are presented, we discuss how students' peer scaffolding differed from the teacher's mediation during classroom DA. Excerpt A begins as students in Group 1 have just sat down to begin their group work and Jamal proposes an idea for the first question.

\section{Excerpt A}

1. Sara: So, what should the first one be?

2. Jamal: What's your favorite football team?

3. Sara: You have to say that in Spanish. (smiles)

4. Mary: You have to say that in Spanish.

5. Jamal: (Jamal makes a face, punches the air, and says "oh man!") Why?

6. Sara: (points to audio recorder)

7. Mary: Okay, so let's break it down

8. Mary: Qué [What]

9. Sara: (shakes her head) What... 
10. Mary: Qué es [What is]

11. Sara: Qué es tu [What is your]

12. Mary: Qué es tu [What is your]

13. Chorus: Qué es tu [What is your]

14. Jamal: favorito [favorite]

15. Mary: favorito [favorite]

16. Sara: favorito doesn't come first

17. Mary: Oh yeah

18. Sara: Qué es tu fútbol [What is your football]

19. Mary: No, there's something...team

20. Sara: ¡equipo! [team!]

21. Mary: Oh, equipo yeah

22. Mary: equipo favorite [favorite team]

23. Sara: How do you spell equipo?

(Mary takes the notebook and writes out equipo)

24. Mary: something like that, right?

Although none of these students were capable of forming a question independently, they were able to use many of the peer scaffolding mechanisms described in the literature to complete their task. In Turn 6, Mary's statement clearly indicates that scaffolding is occurring. By stating, "Let's break this down", she invites her classmates into joint construction. This phrase indicates that Mary understands the compositional nature of the specific task and opts to frame the task by reducing the number of constituent acts into manageable parts for the group, a classic scaffolding 
move well known in the literature (Wood et al., 1976). We also see in Excerpt A that group members used the L1 in Turns 1-6 to set up the task and create a shared orientation (Brooks \& Donato, 1994). Sara begins the group work session by recruiting interest in the task (Wood et al., 1976) with explicit talk about task, asking her peers what question they should record. Jamal responds by suggesting that they ask the visitor about her favorite soccer team. Sara and Mary both use the L1 again to maintain the objective of the task (Wood et al., 1976) by telling Jamal that the question needs to be in Spanish. Interestingly, Mary and Sara both use the singular 'you' in Turns 3 and 4, seemingly indicating that Jamal needs to translate his question to Spanish independently. After this initial orientation, a series of repetitive utterances begins as the group begins to translate the question that Jamal has offered. Mary begins the question in Turn 8 by providing the question word qué [what]. Sara translates this to English and Mary adds the next word es [is]. In Turn 11, Sara repeats qué es [what is] and adds the possessive pronoun tu [your]. Mary repeats these three words in Turn 12, and all members of the group repeat these words again in Turn 13. As the excerpt continues, Jamal adds an adjective in Turn 14, which Mary repeats in Turn 15. This repetition of previous utterances, which Lerner (1991) and Schegloff (1982) refer to as collaborative completion, serves to maintain the focus of attention and to hold the scaffold in place (DiCamilla \& Antón, 1997). As the group continues to translate the initial question suggested by Jamal, Sara 'marks critical features of the task' (Wood et al., 1976) by correctly stating that the adjective does not come first showing an explicit focus on form. Mary confirms this utterance by saying 'oh yeah' and Sara instead offers the word ¿Qué es tu fútbol... [What is your soccer...]. Mary also reverts to the L1 in Turn 19 to point out that another word is still missing by stating, “No, there's something....team”. In Turn 23, Sara goes back to English 
to ask her peers how to spell equipo [team] and Mary responds by writing the word down for Sara.

A second excerpt, Excerpt B below, reveals how Group 2 approached the task differently than Group 1, but still relied on repetition and the L1. In Excerpt B, Elena, Takuya, and Thad have just recorded their first question, ¿Cómo estás? [How are you?]. Thad formed this question without any assistance and announces to Elena in English that it is her turn to form the next one.

\section{Excerpt B}

1. Thad: Okay, I did one. You do one.

2. Elena: Okay, so...

3. Takuya: ¡Buenos tardes! [Good afternoon!]

4. Elena: Qué [What]

5. Takuya: Qué un [What a]

6. Elena: Qué tu [What your]

7. Takuya: Qué como [What like]

8. Thad: favorito [favorite]

9. Elena: What? ¿Qué tu favorito actividad? [What your favorite activity?]

10. Thad: yeah

11. Elena: Can I write this one since I made it up?

12. Takuya: Too bad (writes it himself)

13. Thad: Elena, you can write mine if you want

14. Takuya: (throws paper and pencil at Elena.) I don't want to write it. I don't want to 
misspell it

15. Elena: alright. Qué tu...what [What you...]

16. Thad: actividad [activity]

17. Takuya: favorite [favorite]

18. Thad: actividad favorite [favorite activity]

19. Elena: en Argentina [in Argentina]

20. Thad: en Argentina [in Argentina]

Excerpt B begins as Thad recruits interest to the task (Wood et al., 1976) in English by stating "Okay, I did one. You do one." This statement shows Thad's orientation to the task, one in which he expects his group members to take turns recording questions. Despite Thad's individual conceptualization of this task, Excerpt B illustrates how the orientation to the task quickly shifts as all students collaborate to form the next question. As the excerpt shows, no student seems capable of forming this question independently and each student contributes. In Turns 4-7, Elena and Takuya each suggest the beginning words of the question, repeating the word ¿qué? [what] followed by differing words, none of which are grammatically correct. Elena begins the interaction by offering the question word, Qué [what]. Takuya then repeats Elena's utterance and adds the next word. Elena does not agree with Takuya's suggestion of Qué un... [what a] and she offers Qué tu [what you] instead. Takuya then makes a new suggestion of Qué como [what like] which is ignored again when Thad offers the word favorito [favorite]. In these turns, repetition of the word qué [what] followed by varying words serves to disconfirm the previous utterance and offer a new suggestion. Thad's suggestion of favorito [favorite] is accepted and the formation of the question continues without a verb. In Turn 9, Elena combines 
the contributions from the previous lines and added the word actividad [activity]. This was the first point in time that the students had a shared orientation of the question being formed. Interestingly, Elena, Takuya, and Thad did not use English or translation to form this question. The students reverted to English to talk about the spelling of the words and to decide who would record the question on paper. Thus, in Excerpt B, use of the L1 was used only to manage the demands of the task (Wood et al., 1976), and could be classified as talk about task (Brooks et al., 1997).

Q3 If peer assistance emerges during small group work, how is it similar or different from teacher mediation during DA?

In Excerpts $\mathrm{A}$ and $\mathrm{B}$, it was common for a student to repeat the utterance of a group member, whether it was a single word or an entire phrase. As displayed in Table 1, repetition also accounted for two of the five pre-scripted mediation prompts used by the teacher during classroom DA. On the surface, this suggests that perhaps students appropriated the mediation techniques of their teacher. However, a fundamental difference exists between the repetition by the teacher and the repetition by peers. Excerpt $\mathrm{C}$ highlights a typical exchange between the teacher and a student, Molly, during classroom DA.

\section{Excerpt C}

1. Molly: ¿*Cómo le gusta hacer en Buenos Aires? [How do you like to do in Buenos Aires?]

2. Teacher: Prompt 1 (pauses and looks skeptically at student) 
3. Molly: ¿Cómo... [How...]

4. Teacher: Prompt 2 ¿*Cómo le gusta hacer en Buenos Aires? [How do you like to do in Buenos Aires?]

5. Molly: ¿Dónde? [Where?]

6. Teacher: Prompt 3 ¿Cómo? [How?]

7. Molly: (silence)

8. Teacher: Prompt 4 ¿Cómo o qué? [How or what?]

9. Molly: ¿Qué le gusta hacer? [What do you like to do?]

10. Teacher: Sí, ¿Qué significa qué en ingles? [Yes, what does qué mean in English?]

Excerpt $\mathrm{C}$ occurs in the classroom between the teacher and Molly as other students listen attentively to the interaction. Molly is attempting to form the question 'What do you like to do in Argentina?' but uses the incorrect question word. As a result, the teacher begins to follow the pre-scripted mediation prompts to guide the student in correcting her error. The first prompt, a pause, is not sufficiently explicit for Molly to correct her error; therefore, the teacher provides the second prompt by repeating the entire question. Because this prompt is also not sufficiently explicit as Molly's guess in Turn 5 indicates, the teacher provides the third prompt by repeating the incorrect word. As Turns 4 and 6 reveal, the teacher used repetition as a way to signal to the students that something was incorrect and needed to be fixed. By repeating the incorrect phrase or word, she was providing students the opportunity to re-consider the utterance and perhaps repair her initial response.

In comparing Excerpt $\mathrm{C}$ to Excerpts $\mathrm{A}$ and $\mathrm{B}$, students used repetition for a fundamentally different purpose during small group work than the teacher did during classroom 
DA. Repetition by students served to focus on the task at hand, whereas repetition by the teacher had the goal of cognitively engaging the students in problem-solving, self-correction, or reflection on what was said. For example, when the students repeated an utterance, the repetition served to "distribute the help throughout the activity, and thereby hold the scaffold in place, as it were, creating a cognitive space in which to work (e.g., think, hypothesize, evaluate), and from which to build (i.e., generate more language)" (DiCamilla \& Antón, 1997, pp. 627-628). In contrast, the teacher's fourth mediation prompt was a repetition of a student's incorrect utterance and the correct form in the form of a forced-choice question requiring students to reflect on alternatives and select the appropriate response. This type of forced-choice questioning, a typical leading question in DA, was not present in any of the small group interactions. Therefore, while students were capable of peer scaffolding, their assistance did not meet the definition of mediation.

Another important difference between teacher mediation and peer scaffolding was that the teacher's mediation was graduated and contingent upon students' responses. The teacher offered mediation prompts in an intentional order and only offered explicit prompts when the implicit ones were not sufficient. Excerpts A and B reveal that peer scaffolding was haphazard and not graduated or contingent. That is, peer scaffolding responded to locally emerging concerns whereas teacher mediation was provided based on past performance and an assessment of how current performance was related to the type of assistance that addressed the learner's future and potential for growth. On the surface, peer scaffolding resembled forms of interactionist DA where no immediate instructional objective is the focus and help is unscripted and provided as the need arises in the task (Lantolf \& Poehner, 2004). This type of DA stands in contrast to the interventionist format of DA in which clear language learning objectives are 
identified and contingent mediation is pre-determined by a series of scripted prompts. ${ }^{3}$ In other words, students are capable of offering assistance dynamically as they scaffold task solutions in the context of interaction. Where peer scaffolding differs fundamentally from a teacher's mediation is that students are not explicitly assessing where group members are within the ZPD to help them move beyond concrete perceptions of task components to underlying concepts. Assistance through scaffolding deals with local concerns of task completion during which the expert simplifies the complexity of the task in order to involve the novice in its completion. Here the overarching goal is to transfer responsibility for task completion to the novice. DA, on the other, incorporates, at times, similar features of scaffolding but works toward the goal of conceptual development. Consistent with Vygotsky’s (1994) view, to develop means that individuals move from exclusively perceptual (what you see and how you see it) and verbal (what you say and how you say it) ways of knowing to the use of concepts (what you think and why you think it) for carrying out diverse activities using language for one's own purposes and intentions across a variety of contexts.

\section{Conclusions}

In summary, despite their varying orientations to the task and varying levels of proficiency, each group was able to collaborate to successfully create a list of questions (Tables 3 and 4) by taking responsibility for assisting each other. As Donato (1994) states, "During the interaction, the speakers are at the same time individually novices and collectively experts, sources of new orientation for each other, and guides through this complex linguistic problem solving" (p. 46). The findings in the present study provided further evidence that scaffolded help is not limited to 
expert-novice pairings (DiCamilla \& Antón, 1997; Swain \& Lapkin, 1998). Although Groups 1 and 2 were composed of students at various sublevels (Low, Mid, and High) in the Novice range of proficiency, there was no 'expert' in their interactions. Through examination of the dialogue, it was difficult to label students as either experts or novices as reversals in these roles were common (Ohta, 2001).

We return here to the distinction described earlier between mediation and scaffolding. Lantolf and Thorne (2006) distinguish mediation from scaffolding stating that the goal of mediation is to help the learner develop, whereas the goal of scaffolding is the learning of specific procedures required for successful task completion. We argue that scaffolding is a valuable form of assistance that often manifests itself in ways similar to that of mediation, such as repetition and use of the L1. Scaffolding can also be seen during certain stages of DA sessions as a way to diagnose the ZPD of the learner and as a precursor to subsequent interactive work aimed at developing a conceptual understanding of the particular aspect of language either targeted for intervention or spontaneously emerging during interaction. Although peer scaffolding was somewhat self-serving, the students in Groups 1 and 2 seemed to take into account each other's ZPD, perhaps because it was similar to that of their own. Despite the differences in peer scaffolding and teacher mediation, scaffolding represents a legitimate form of assistance that plays a crucial role in language education, particularly in classroom settings. Lantolf and Thorne (2006) concur that "peer interaction should be included among participant structures conducive to learning through the ZPD, especially in secondary and higher education settings" (p. 288). As sociocultural theory maintains, learning and development are inextricably connected. From this perspective, scaffolding sets the stage for building upon context-specific 
task language learning that can then serve as the basis for increasing greater control of language applied to various contexts of language use.

The implications of the present work suggest that small group collaborative tasks be used in conjunction with classroom DA. Perhaps not surprisingly, students untrained in mediating their peers assisted each other in ways quite different from mediation provided within the DA framework. Regardless, the forms of peer scaffolding that occurred led to successful task completion. Whether these forms of peer scaffolding led to conceptual development, which is the goal of DA, requires more research evidence than the present study can provide. Another area of investigation might involve varying the types of tasks that students are given during small group work to see if peer assistance interacts with task features in a way that leads to broader conceptual understandings rather than simply task compliance and completion (see White, 2012, for an example of a conceptual task for English phrasal verbs). We strongly agree that classroom DA is a useful tool for enabling teachers to unite teaching and assessment and for moving students to conceptual understandings of their new language. However, what the present study indicates is that, within the classroom setting in which time is limited, classroom DA may not be sufficient for the language development of all students, and other forms of assistance must be put into place to allow for more individualized collaborative interactions than are not always available in a whole class setting. In addition to peer scaffolding that small group post-DA sessions provide, student interactions allow for targeted help on specific task features to all group members while simultaneously providing a window to the teacher for monitoring the outcomes of whole class instruction and for planning subsequent whole class DA sessions. In this way, small group interaction complements DA and supports the work of teachers seeking to implement DA in a consistent and equitable way in their language classes. 
Notes

1. We are aware that students most likely would not have the same goals, background knowledge, and pedagogical training as teachers when working together and therefore cannot be expected to mimic the type of mediation provided by the teacher (assistance graduated from implicit to more explicit cues and a reduction in assistance as students develop particular aspects of a task). What is relevant to this study, however, is whether assistance is available in the small group context, whether any of this assistance reflected previous mediation by the teacher, and how this peer assistance might complement (Davin, in press) whole class dynamic assessment. 2. This could be due to the novel presence of the video camera and audio recorder. Regardless, this topic is beyond the scope of the present study.

3. In the current DA literature in L2 learning, a distinction has been made between interventionist and interactionist approaches to DA. This distinction is not as clear within the classroom context. We maintain that all cases of DA take place in the context of interaction and involve an intervention of some kind, be it scripted or unscripted, 'caked' or 'sandwiched' (Lantolf \& Poehner, 2004).

\section{References}

Ableeva, R. (2008). The effects of dynamic assessment on L2 listening comprehension. In J. P. Lantolf \& M. E. Poehner (Eds.), Sociocultural theory and the teaching of second languages (pp. 57-86). London, UK: Equinox.

Aljaafreh, A., \& Lantolf, J. P. (1994). Negative feedback as regulation and second language learning in the zone of proximal development. The Modern Language Journal, 78(4), 465-483. 
Alley, D. C. (2005). A study of Spanish II high school students' discourse during group work. Foreign Language Annals, 38(2), 250-257.

Antón, M. (2009). Dynamic assessment of advanced second language learners. Foreign Language Annals, 42(3), 576-598.

Antón, M., \& DiCamilla, F. (1998). Socio-cognitive functions of L1 collaborative interaction in the L2 classroom. The Canadian Modern Language Review, 54(3), 314-342.

Brooks, F. B., \& Donato, R. (1994). Vygotskian approaches to understanding foreign language learner discourse during communicative tasks. Hispania, 77(2), 262-274.

Brooks, F. B., Donato, R., \& Mcglone, J. V. (1997). When are they going to say "It" right? Understanding learner talk during pair-work activity. Foreign Language Annals, 30(4), 524-541.

Chaiklin, S. (2003). The zone of proximal development in Vygotsky's analysis of learning and instruction. In A. Kozulin, B. Gindis, V. S. Ageyev, \& S. M. Miller (Eds.), Vygotsky's educational theory in cultural context (pp. 39-63). Cambridge, UK: Cambridge University Press.

Cole, M., \& Engeström, Y. (1993). A cultural-historical approach to distributed cognition. In G. Salomon (Ed.), Distributed cognititions: Psychological and educational considerations (pp. 146). Cambridge, UK: Cambridge University Press.

Curtain, H., \& Dahlberg, C. A. (2010). Languages and children: Making the match (4th ed.). Glenview, IL: Pearson/Prentice Hall.

Davin, K. J. (in press). Integration of dynamic assessment and instructional conversations to promote development and improve assessment in the language classroom. Language Teaching Research.

Davin, K. J. (2011). Group dynamic assessment in an early foreign language learning program: Tracking movement through the zone of proximal development. (Doctoral Dissertation. University of Pittsburgh). Retrieved from http://dscholarship.pitt.edu/7269/1/DAVINKJ_ETD.pdf

Davin, K. J., Troyan, F. J., Donato, R., \& Hellman, A. (2011). Research on the integrated performance assessment in an early foreign language learning program. Foreign Language Annals, 44(4), 605-625. doi:10.1111/j.1944-9720.2011.01153.x

De Guerrero, M. C., \& Villamil, O. S. (2000). Activating the ZPD: Mutual scaffolding in L2 peer revision. The Modern Language Journal, 84(1), 51-68.

de la Colina, A. A., \& García Mayo, M. (2006). Attention to form across collaborative tasks by low-proficiency learners in an EFL setting. In M. García Mayo (Ed.), Investigating tasks in formal language learning (pp. 91-116). Multilingual Matters. 
DiCamilla, F. J., \& Antón, M. (1997). Repetition in the collaborative discourse of L2 learners: A Vygotskian perspective. The Canadian Modern Language Review, 53(4), 609-633.

Donato, R. (1994). Collective scaffolding in second language learning. In J. P. Lantolf \& G. Appel (Eds.), Vygotskian approaches to second language research (pp. 33-56). Norwood, NJ: Ablex.

Foster, P. (2005). Negotiation for meaning and peer assistance in second language classrooms. Applied Linguistics, 26(3), 402-430. doi:10.1093/applin/ami014

Lantolf, J. P. (2000). Second language learning as a mediated process. Language Teaching, 33, 79-96.

Lantolf, J. P., \& Poehner, M. E. (2004). Dynamic assessment of L2 development: Bringing the past into the future. Journal of Applied Linguistics, 1(1), 49-72.

Lantolf, J. P., \& Poehner, M. E. (2011a). Dynamic assessment in the classroom: Vygotskian praxis for second language development. Language Teaching Research, 15(1), 323-340. doi: $10.1177 / 1362168810383328$

Lantolf, J. P., \& Poehner, M. E. (2011b). Dynamic assessment in the foreign language classroom: A teacher's guide (2nd ed.). University Park, PA: CALPER.

Lantolf, J. P., \& Thorne, S. L. (2006). Sociocultural theory and the genesis of second language development. Oxford, UK: Oxford University Press.

Lave, J., \& Wenger, E. (1991). Situated learning: Legitimate peripheral participation. Cambridge, UK: Cambridge University Press.

Leeser, M. J. (2004). Learner proficiency and focus on form during collaborative dialogue. Language Teaching Research, 8(1), 55-81. doi:10.1191/13621688041r134oa

Lerner, G. H. (1991). On the syntax of sentences-in-progress. Language in Society, 20, 441-458.

Lidz, C. S., \& Gindis, B. (2003). Dynamic assessment of the evolving cognitive functions in children with typical and atypical development. In A. Kozulin, V. Ageyev, S. Miller, \& B. Gindis (Eds.), Vygotsky's theory of education in cultural context (pp. 99-116). New York, NY: Cambridge University Press.

Mackey, A., Oliver, R., \& Leeman, J. (2003). Interactional input and the incorporation of feedback: An exploration of NS-NNS and NNS-NNS adult and child dyads. Language Learning, 53(1), 35-66.

Nunan, D. (1992). Sociocultural aspects of second language acquisition. Cross Currents, 19, 1324. 
Ohta, A. S. (2000). Re-thinking interaction in SLA: Developmentally appropriate assistance in the zone of proximal development and the acquisition of L2 grammar. In J.P. Lantolf (Ed.), Sociocultural theory and second language learning (pp. 51-78). Oxford, UK: Oxford University Press.

Ohta, A. S. (2001). Second language acquisition processes in the classroom. Mahwah, NJ: Lawrence Erlbaum Associates.

Ohta, A. S. (2005). Confirmation checks $\square$ : A discourse analytic reanalysis. Japanese language and literature, 39(2), 383-412.

Oliver, R. (1998). Negotiation of meaning in child interactions. The Modern Language Journal, 82(3), 372-386.

Oliver, R. (2000). Age differences in negotiation and feedback in classsroom and pairwork. Language Learning, 50(1), 119-151.

Oliver, R. (2002). The patterns of negotiation for meaning in child interactions. The Modern Language Journal, 86(1), 97-111.

Oliver, R., \& Mackey, A. (2003). Interactional context and feedback in child ESL classrooms. The Modern Language Journal, 87(4), 519-533. doi:10.1111/1540-4781.00205

Poehner, M. E. (2005). Dynamic assessment among advanced L2 learners of French. (Doctoral dissertation, The Pennsylvania State University). Retrieved from https://etda.libraries.psu.edu/paper/6627/1890

Poehner, M. E. (2007). Beyond the test: L2 dynamic assessment and the transcendence of mediated learning. The Modern Language Journal, 91(3), 323-340.

Poehner, M. E. (2008). Dynamic assessment: A Vygotskian approach to understanding and promoting L2 development (pp. 1-201). Berlin, DE: Springer.

Poehner, M. E. (2009). Group dynamic assessment: Mediation for the L2 classroom. TESOL Quarterly, 43(3), 471-491.

Schegloff, E. A. (1982). Discourse as an interactional achievement: Some uses of "uh huh" and other things that come between sentences. In D. Tannen (Ed.), Analyzing discourse: Text and talk (pp. 71-93). Washington, D.C.: Georgetown University Press.

Schegloff, E. A. (1993). Reflections on quantification in the study of conversation. Research on Language and Social Interaction, 26(1), 99-128.

Smith, R. A. (1987). A teacher's view on cooperative learning. Phi Delta Kappan, 68(9), 663666. 
Storch, N. (2001). How collaborative is pair work? ESL tertiary students composing in pairs. Language Teaching Research, 5(1), 29-53. doi:10.1177/136216880100500103

Storch, N. (2002). Patterns of interaction in ESL pair work. Language Learning, 52(1), 119-158.

Storch, N. (2005). Collaborative writing: Product, process, and students' reflections. Journal of Second Language Writing, 14, 153-173.

Storch, N. (2011). Collaborative writing in L2 contexts: Processes, outcomes, and future directions. Annual Review of Applied Linguistics, 31, 275-288.

Storch, N., \& Aldosari, A. (2010). Learners' use of first language (Arabic) in pair work in an EFL class. Language Teaching Research, 14(4), 355-375. doi:10.1177/1362168810375362

Swain, M. (2006). Languaging, agency and collaboration in advanced second language proficiency. In H. Byrnes (Ed.), Advanced language learning: The contributions of Halliday and Vygotsky (pp. 95-108). London: Continuum.

Swain, M., \& Lapkin, S. (1998). Interaction and second language learning: Two adolescent French immersion students working together. The Modern Language Journal, 82(3), 320-337.

Swain, M., \& Lapkin, S. (2000). Task-based second language learning: The uses of the first language. Language Teaching Research, 4(3), 251-274. doi:10.1177/136216880000400304

Swain, M., Lapkin, S., Knouzi, I., Suzuki, W., \& Brooks, L. (2009). Languaging: University students learn the grammatical concept of voice in French. The Modern Language Journal, 93(1), 5-29. doi:10.1111/j.1540-4781.2009.00825.x

Valsiner, J. (2001). Process structure of semiotic mediation in human development. Human Development, 44, 84-97.

van Lier, L. (2000). From input to affordance: Social-interactive learning from an ecological perspective. Sociocultural theory and second language learning (pp. 245-259).

Villamil, O. S., \& De Guerrero, M. C. M. (1996). Peer revision in the L2 classroom: Socialcognitive activities, mediating strategies, and aspects of social behavior. Journal of Second Language Writing, 5(1), 51-75.

Vygotsky, L. (1978). Mind in society: The development of higher mental processes. Cambridge, MA: Harvard University Press.

Vygotsky, L. (1986). Thought and language. Cambridge, MA: MIT Press.

Vygotsky, L. S. (1997). The collected works of L. S. Vygotsky, Vol. 4. The history of the development of higher mental functions (R. W. Rieber, Ed.; M. J. Hall, Trans.). New York, NY: Plenum Press. (Original work published 1931) 
Weissberg, R. (2006). Connecting speaking and writing. Ann Arbor, MI: University of Michigan Press.

Wells, G. (1999). Dialogic inquiry: Towards a sociocultural practice and theory of education. Cambridge, UK: Cambridge University Press.

Wertsch, J. V. (1979). The regulation of human action and the given-new organization of private speech. In G. Zivin (Ed.), The development of self-regulation through private speech (pp. 7898). New York, NY: John Wiley \& Sons.

Wertsch, J. V. (1985). Vygotsky and the social formation of mind. Cambridge, MA: Harvard University Press.

Wertsch, J. V., \& Hickmann, M. (1987). Problem solving in social interaction: A microgenetic analysis. In M. Hickmann (Ed.), Social and functional approaches to language and thought (pp. 251-266). Orlando, FL: Academic Press, Inc.

White, B. J. (2012). A conceptual approach to the instruction of phrasal verbs. The Modern Language Journal, 96(3), 419-438. doi:10.1111/j.1540-4781.2012.01365.x

Wood, D., Bruner, J., \& Ross, G. (1976). The role of tutoring in problem solving. Journal of Child Psychology and Psychiatry, 17, 89-100. 